Review article

\title{
Adverse events in anaesthesia care
}

\author{
Petra Bejvančická ${ }^{1,2}$ * Iva Brabcová $^{1}$ \\ ${ }^{1}$ University of South Bohemia in České Budějovice, Faculty of Health and Social Sciences, České Budějovice, Czech Republic \\ ${ }^{2}$ University of West Bohemia, Faculty of Health Care Studies, Plzeň, Czech Republic
}

\begin{abstract}
The goal of this review study was to summarize research conclusions on reported adverse events in anaesthesia care regarding paediatric and adult patients in the last 10 years.

Methods: Relevant sources were found in scientific databases EBSCO, PubMed, Science Direct, Wiley and Scopus. We used the following keywords: adverse events/incident/malpractice, anaesthesia, report. Other criteria for the inclusion of studies were: full-text, English language, publications that were no older than 10 years (2009-2019) and human related. In the end, we included 15 studies.

Results: The studies (analytical, prospective, retrospective, cohort, observational, systematic revisions and meta-analyses) mostly specify the areas and frequencies of reported adverse events and deal with the efficiency of report procedures and their implementation in clinical practice. The most frequent adverse events that occurred in anaesthesia care were respiration and cardiovascular problems and medical errors. The level of their occurrence varied by the patients' age.

Conclusions: The monitoring and assessment of adverse events is an effective instrument for the improvement of quality and safety in anaesthesia practical care. The main problem is the unwillingness of medical workers to participate in reporting adverse events and the incompatibility of adverse event databases in anaesthesia care.
\end{abstract}

Keywords: Adverse event; Anaesthesia; Patient safety; Perioperative care; Report

\section{Introduction}

In the last few years, increased attention has been paid to patient safety. Monitoring adverse events/incidents has been widely accepted as a useful tool for the improvement of quality and the maintenance of high safety standards in anaesthesia care (Smith and Mahajan, 2009). Incident reports can be used for examining latent and active errors, and for the analysis or remedial and preventative strategies (MacLennan and Smith, 2011).

In foreign sources, the occurrence of adverse events is mentioned, but to a different extent. According to Levinson (2010), it is estimated that $13.5 \%$ of hospitalized patients have experienced an adverse event and, in $1.5 \%$ of cases, the event led to death. The possibilities for preventing adverse events are from $17 \%$ to $76.5 \%$ (Vlayen et al., 2012).

Insufficient patient safety is a serious problem, both for public health and the economy of limited healthcare resources. Many adverse events of hospitalized and outpatient patients can be prevented, because it is obvious that most of them are caused by system factors. However, errors can never be completely eliminated in healthcare, because they are associated with the human factor. Health service providers should focus on minimizing risks and their impacts, and on the improvement of the methods of timely detection of these errors.
The Ministry of Health of the Czech Republic defines adverse events $(\mathrm{AE})$ as circumstances that could end or have ended in a patient's physical, mental or socio-economical harm. Health service providers or their employees can also be harmed. If there is an unexpected deterioration of a patient's health condition that results in permanent damage or death, it is considered an adverse event. AE includes situations that were identified before a patient's or another person's harm. These errors that nearly happened are called "almost-errors" or "near misses". In the Czech Republic, AE is identified as situations that include completed and uncompleted errors. The WHO uses the term "incident", which partially corresponds with the mentioned definition. The incidents are classified as follows: "uncompleted errors", "incidents with no harm to a patient", "incidents with harm to a patient". According to the WHO, only the last group is classified as "adverse events" (Pokorná et al., 2018).

The reporting of adverse events/critical incidents is a system that enables these events to be described and analyzed (Woods et al., 2005).

The term anaesthesia care includes pre-anaesthetic examination and the related consultation work, the performance of individual techniques of anaesthesia - total anaesthesia, regional anaesthesia (central and peripheral blockings), and monitored perioperative care (includes "analgesic sedation" or “anaesthetic surveillance”) (ČSARIM, 2017).

\footnotetext{
* Author for correspondence: Petra Bejvančická, University of South Bohemia in České Budějovice, Faculty of Health and Social Sciences, J. Boreckého 1167/27, 37011 Ceské Budějovice, Czech Republic; e-mail: pbejvanc@kos.zcu.cz http://doi.org/10.32725/kont.2020.011

Submitted: 2020-01-10 • Accepted: 2020-03-30 • Prepublished online: 2020-04-16 
Flanagan first presented the critical incident analysis in 1954, and it was used in aviation to improve safety and performance. In 1978, Cooper and coll. used the modified critical incident analysis technique to define the pattern of frequently occurring incidents that led to anaesthetic failures or patient harm. $82 \%$ of accidents included human errors that could be prevented, and instrument malfunction played a part in $14 \%$. Anaesthesiology became a pioneer specialization in the assessment and development of adverse event preventative activities (Gaba, 2000) and the use of adverse event reports for the improvement of patient safety (Choy, 2008). There are many global adverse events/critical incidents report programmes that have been implemented, such as American Society of Anesthesiologists (ASA), Committee on Patient Safety and Risk Management, Anesthesia Patient Safety Foundation (APSF) and National Patient Safety Agency in Great Britain, and the Australian Incident Monitoring System (AIMS) in Australia (Mahajan, 2010).

In June 2010, the European Board of Anaesthesiology (EBA) and the European Society of Anaesthesiology (ESA) issued the Helsinki Declaration for Patient Safety in Anaesthesiology. This declaration emphasized the crucial role of anaesthesiology in the propagation of safe perioperative care. The basic requirements for all institutions that provide anaesthesia care include the necessity of collecting the necessary data for annual patient morbidity and mortality assessment. The requirements also include being involved in national and other significant audits regarding medical care safety, as well as adverse event/critical incident reporting systems (Mellin-Olsen et al., 2010).

\section{Materials and methods}

This is a review study. We set the clinical question of $\mathrm{PI}(\mathrm{C})$ OT (Patient, Issue of interest, Comparison, Outcome, Time): What adverse events $(\mathrm{I})$ are reported $(\mathrm{O})$ regarding patients $(\mathrm{P})$ in anaesthesia care $(\mathrm{T})$ ?

We used the method of content analysis. The included studies and articles were found in full-text databases (Waley, Cinahl, Ebsco, Science Direct) and citation databases (Pub Med, Scopus), which were used for finding secondary sources. We used the following keywords: "anesthesia/anesthesiology", "adverse events/effects/incident/malpractice", "report", "human". We used the Boole operators "and" and "or". The criteria for the inclusion of the documents were as follows: human patients in anaesthesia care, timeline between 2009 and 2019, focus on reporting and assessing adverse events. The criteria for exclusion included: studies older than 10 years, inconsistency with $\mathrm{PI}(\mathrm{C}) \mathrm{OT}$, articles that were focused on special types of anaesthesia care or veterinarian anaesthesia. The sources were in English.

After using the keyword, we found 1,475 sources. We filtered the conclusions by titles and abstracts and got to 110 results. After studying the abstracts, we searched for full-texts of the relevant and potentially relevant articles (fully or partially fulfilling the established criteria). In the next phase, we removed the duplicates and publications that did not deal with the studied issue in the required context and publications whose fulltexts were not available. The final number of publications that we used in our study was 15 (Diagram 1). Data collection and analyses were carried out between June and August 2019.

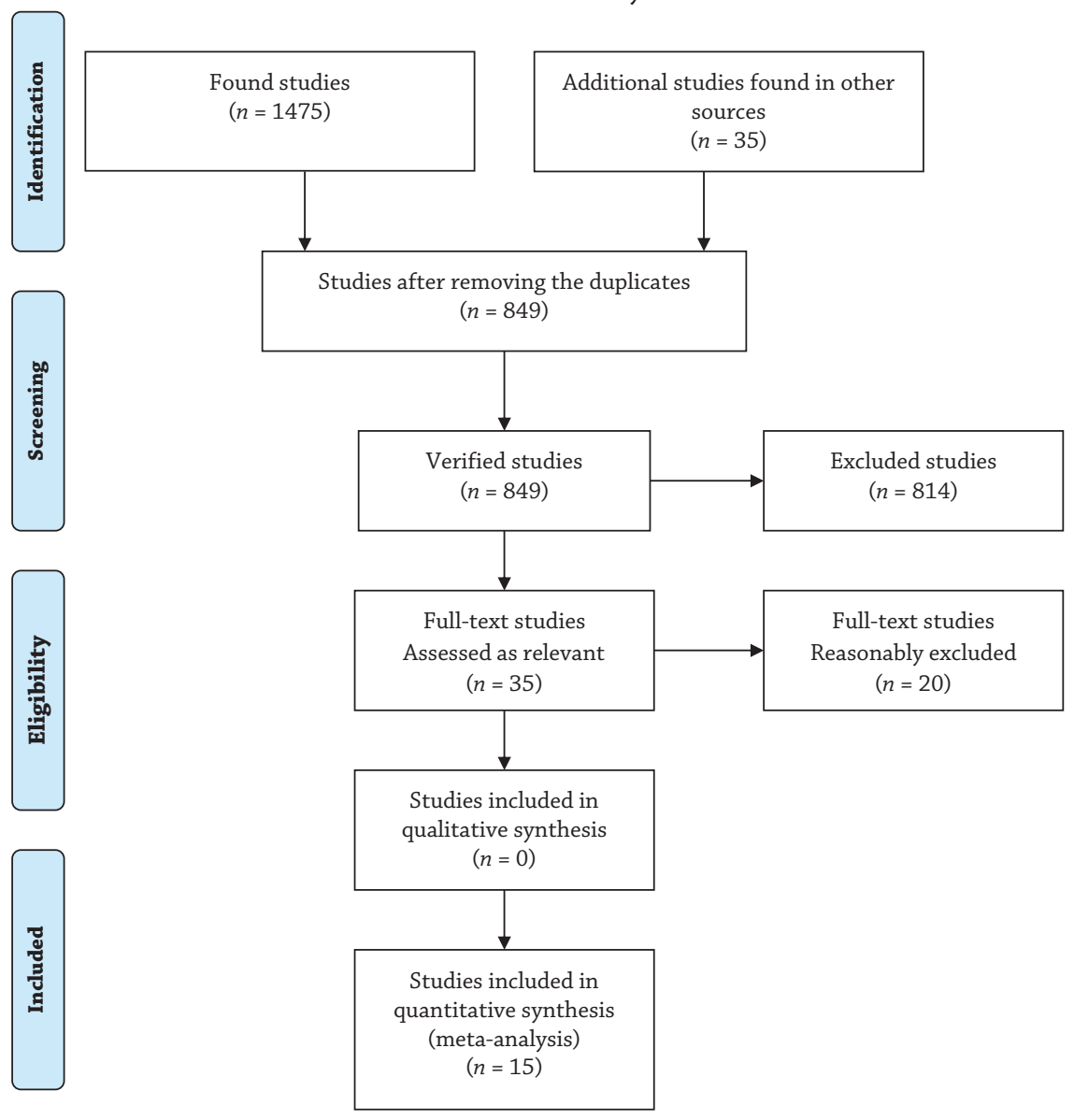

Diagram 1. Prisma flow diagram 


\section{Sample group}

In the analyzed studies, reported adverse events were related only to children (0-18) and one study dealt with pregnant women.

The number of reported adverse events in the sample group was between 85 and 3,904, and the number of performed an- aesthesia procedures was between 1,206 and 257,000. We used between 21 and 55 studies for meta-analyses. Only some studies provided the specific research environment (most frequently, they were specific hospitals) and others used the $\mathrm{AE}$ databases.

\section{Table 1. Used studies}

\begin{tabular}{|c|c|c|c|c|c|}
\hline $\begin{array}{l}\text { Author, publishing } \\
\text { year, country }\end{array}$ & Period & $\begin{array}{l}\text { Sample group of } \\
\text { respondents }\end{array}$ & Environment & Study type & Research goal \\
\hline $\begin{array}{l}\text { de Santana Lemos } \\
\text { and de Brito } \\
\text { Poveda, 2019, } \\
\text { Brazil }\end{array}$ & 1997-2017 & Adults & $\begin{array}{l}10 \text { studies were } \\
\text { published in the } \\
\text { USA; others were not } \\
\text { specified }\end{array}$ & $\begin{array}{l}\text { Integrative review } \\
21 \text { studies }\end{array}$ & $\begin{array}{l}\text { To identify adverse events in } \\
\text { perioperative care that are } \\
\text { related to anaesthesia. }\end{array}$ \\
\hline $\begin{array}{l}\text { Habre et al., 2017, } \\
\text { Switzerland }\end{array}$ & $\begin{array}{l}4 / 2014- \\
1 / 2015\end{array}$ & $\begin{array}{l}\text { Children up to } \\
15 \text { years } \\
31,127 \\
\text { anaesthesias }\end{array}$ & $\begin{array}{l}261 \text { medical care } \\
\text { centres in } 33 \text { European } \\
\text { countries }\end{array}$ & $\begin{array}{l}\text { APRICOT prospective } \\
\text { observational multicentric } \\
\text { cohort study }\end{array}$ & $\begin{array}{l}\text { To find the incidence, types and } \\
\text { results of serious and critical } \\
\text { events in children who are } \\
\text { undergoing anaesthesia (which } \\
\text { is related to potential risk } \\
\text { factors). }\end{array}$ \\
\hline $\begin{array}{l}\text { Williams et al., } \\
\text { 2017, USA }\end{array}$ & $\begin{array}{l}\text { 11/2010- } \\
9 / 2016\end{array}$ & $\begin{array}{l}\text { Children } \\
\text { 2,689 AE }\end{array}$ & $\begin{array}{l}\text { Lucile Packard } \\
\text { Children's Hospital } \\
\text { Stanford, California }\end{array}$ & $\begin{array}{l}\text { Quantitative - incident } \\
\text { assessment } \\
\text { Qualitative - the assessment } \\
\text { of the implementation of a } \\
\text { quality improvement system }\end{array}$ & $\begin{array}{l}\text { To increase the speed of incident } \\
\text { reports by anaesthesiologists; to } \\
\text { characterize the behaviour and } \\
\text { co-operation of the reporting } \\
\text { people. }\end{array}$ \\
\hline $\begin{array}{l}\text { Dias et al., 2016, } \\
\text { India }\end{array}$ & $\begin{array}{l}1-12 / \\
2006\end{array}$ & $\begin{array}{l}\text { Children up to } \\
15 \text { years } \\
108 \mathrm{AE} / 1,206 \\
\text { anaesthesias }\end{array}$ & $\begin{array}{l}\text { University hospital in } \\
\text { Mumbai }\end{array}$ & $\begin{array}{l}\text { Prospective observational } \\
\text { study }\end{array}$ & $\begin{array}{l}\text { To study the incidence of } \\
\text { adverse events and classify } \\
\text { them; to formulate them for } \\
\text { reporting systems. }\end{array}$ \\
\hline $\begin{array}{l}\text { Bellolio et al., } \\
\text { 2016a, USA }\end{array}$ & 2005-2015 & $\begin{array}{l}\text { Adults } \\
9,652 \text { sedations }\end{array}$ & Emergency department & $\begin{array}{l}\text { Systematic review and meta- } \\
\text { analysis } \\
55 \text { studies }\end{array}$ & $\begin{array}{l}\text { To assess the incidence of } \\
\text { adverse events in adults who } \\
\text { are sedated during emergency } \\
\text { department. }\end{array}$ \\
\hline $\begin{array}{l}\text { Bellolio et al., } \\
\text { 2016b, USA }\end{array}$ & 2005-2015 & $\begin{array}{l}\text { Children }(\leq 18 \\
\text { years) } \\
13,883 \text { sedations }\end{array}$ & Emergency department & $\begin{array}{l}\text { Systematic review and meta- } \\
\text { analysis } \\
41 \text { studies }\end{array}$ & $\begin{array}{l}\text { To assess the incidence of } \\
\text { adverse events regarding } \\
\text { sedation in children. }\end{array}$ \\
\hline $\begin{array}{l}\text { Munting et al., } \\
\text { 2015, Netherlands }\end{array}$ & $\begin{array}{l}1 / 2005- \\
5 / 2011\end{array}$ & $\begin{array}{l}\text { Adults } \\
3,904 \mathrm{AE} / \\
110,310 \\
\text { anaesthesias }\end{array}$ & $\begin{array}{l}\text { University Medical } \\
\text { Center Utrecht, } \\
\text { Netherlands }\end{array}$ & Observational cohort study & $\begin{array}{l}\text { To identify and analyze critical } \\
\text { incidents that are related to } \\
\text { anaesthesia. }\end{array}$ \\
\hline $\begin{array}{l}\text { de Graaff et al., } \\
\text { 2015, Netherlands }\end{array}$ & $\begin{array}{l}1 / 2007- \\
8 / 2013\end{array}$ & $\begin{array}{l}\text { Children }(\leq 18 \\
\text { years }) \\
1,214 \mathrm{AE} / \\
35,190 \\
\text { anaesthesias }\end{array}$ & $\begin{array}{l}\text { Paediatric university } \\
\text { hospital Wilhelmina, } \\
\text { University medical } \\
\text { centre Utrecht, } \\
\text { Netherlands }\end{array}$ & Cohort study & $\begin{array}{l}\text { To identify and analyze AE } \\
\text { that are related to paediatric } \\
\text { anaesthesia and to identify } \\
\text { areas of improvement in } \\
\text { contemporary clinical practice; } \\
\text { to suggest a specialized } \\
\text { registration of AE. }\end{array}$ \\
\hline $\begin{array}{l}\text { Mir Ghassemi et al., } \\
\text { 2015, Canada, UK }\end{array}$ & $\begin{array}{l}1984- \\
10 / 2013\end{array}$ & $\begin{array}{l}\text { Children } \\
\text { ( }<18 \text { years) }\end{array}$ & Perioperative care & $\begin{array}{l}\text { Systematic review and meta- } \\
\text { analysis } \\
25 \text { articles }\end{array}$ & $\begin{array}{l}\text { To identify complications from } \\
\text { the point of view of frequency } \\
\text { and results. }\end{array}$ \\
\hline $\begin{array}{l}\text { D’Angelo et al., } \\
\text { 2014, USA }\end{array}$ & $\begin{array}{l}10 / 2004- \\
6 / 2009\end{array}$ & $\begin{array}{l}85 \mathrm{AE} / \\
257,000 \\
\text { anaesthesias }\end{array}$ & $\begin{array}{l}30 \text { institutions that } \\
\text { provide medical care } \\
\text { SCORE project }\end{array}$ & SCORE project assessment & $\begin{array}{l}\text { To find the incidence of serious } \\
\text { complications that are related } \\
\text { to obstetric anaesthesia and to } \\
\text { identify risk factors related to } \\
\text { any complication. }\end{array}$ \\
\hline $\begin{array}{l}\text { Kurth et al., 2014, } \\
\text { USA }\end{array}$ & $\begin{array}{l}1 / 2010- \\
1 / 2013\end{array}$ & $\begin{array}{l}740 \mathrm{AE} / \\
736,365 \\
\text { anaesthesias }\end{array}$ & $\begin{array}{l}\text { Centre of anaesthesia } \\
\text { care in the USA, } \\
\text { WUS databasis (Wake } \\
\text { Up Safe) }\end{array}$ & $\begin{array}{l}\text { For the description of the } \\
\text { WUS programme, the SQUIRE } \\
\text { (Standards for Quality } \\
\text { Improvement Reporting } \\
\text { Excellence) programme was } \\
\text { used }\end{array}$ & $\begin{array}{l}\text { To document adverse event } \\
\text { incidence and type on the } \\
\text { national level using the WUS } \\
\text { databasis. }\end{array}$ \\
\hline $\begin{array}{l}\text { Wan et al., 2013, } \\
\text { Singapore }\end{array}$ & $2000-2010$ & $\begin{array}{l}\text { Children } \\
\text { 2,519 AE/ } \\
75,331 \\
\text { anaesthesias }\end{array}$ & $\begin{array}{l}\text { Paediatric faculty } \\
\text { hospital in Singapore }\end{array}$ & Retrospective analysis & $\begin{array}{l}\text { To analyze critical incidents } \\
\text { in paediatric anaesthesia } \\
\text { and related factors in the } \\
\text { institution. }\end{array}$ \\
\hline
\end{tabular}


Table 1. (continued)

\begin{tabular}{|c|c|c|c|c|c|}
\hline $\begin{array}{l}\text { Author, publishing } \\
\text { year, country }\end{array}$ & Period & $\begin{array}{l}\text { Sample group of } \\
\text { respondents }\end{array}$ & Environment & Study type & Research goal \\
\hline $\begin{array}{l}\text { Narasethkamol et } \\
\text { al., 2011, Thailand }\end{array}$ & $1-12 / 2007$ & $\begin{array}{l}0-86 \text { years } \\
191 \mathrm{AE}\end{array}$ & $\begin{array}{l}\text { Faculty hospital in } \\
\text { Bangkok }\end{array}$ & $\begin{array}{l}\text { Prospective multicentric study } \\
\text { (Thai Anesthesia Incident } \\
\text { Monitoring Study) }\end{array}$ & $\begin{array}{l}\text { To find the frequency, clinical } \\
\text { process, factors that contribute, } \\
\text { and factors that minimize } \\
\text { adverse events, and to study } \\
\text { the model that is suitable for } \\
\text { possible remedial strategies in } \\
\text { Thai faculty hospitals. }\end{array}$ \\
\hline $\begin{array}{l}\text { MacLennan and } \\
\text { Smith 2011, } \\
\text { England and Wales }\end{array}$ & $\begin{array}{l}1 / 2006- \\
12 / 2008\end{array}$ & $\begin{array}{l}\text { Children } \\
\text { ( }<15 \text { years) } \\
606 \mathrm{AE}\end{array}$ & $\begin{array}{l}\text { Centre of anaesthesia } \\
\text { care in England and } \\
\text { Wales }\end{array}$ & $\begin{array}{l}\text { The analysis of all-state } \\
\text { reported cases }\end{array}$ & $\begin{array}{l}\text { To identify and analyze } \\
\text { related critical incidents of } \\
\text { paediatric anaesthesia from } \\
\text { NRLS (National Reporting and } \\
\text { Learning System) in England } \\
\text { and Wales. }\end{array}$ \\
\hline $\begin{array}{l}\text { Gupta et al., 2009, } \\
\text { India }\end{array}$ & $\begin{array}{l}12 / 2006- \\
12 / 2007\end{array}$ & $\begin{array}{l}\text { Children and } \\
\text { adults } \\
112 \mathrm{AE} / \\
14,134 \\
\text { anaesthesias }\end{array}$ & $\begin{array}{l}\text { University hospital in } \\
\text { Rajasthan }\end{array}$ & Observational study & $\begin{array}{l}\text { To study potential risk factors } \\
\text { and analyze events that lead to } \\
\text { peroperative critical incidents, } \\
\text { the goal of which was to develop } \\
\text { a system of critical incident } \\
\text { reporting. }\end{array}$ \\
\hline
\end{tabular}

\section{Results and discussion}

In the selected studies, we found the following data: the authors, publishing years, countries, the types of respondents (child/adult), sample groups, the types of research, the goals of the researches (Table 1 ), results and practical conclusions (Table 2).
Of the 15 analyzed studies, 5 were American, 2 were Dutch, 2 were Indian, and 1 were Canadian, Swiss, Brazilian, Singaporean, Thai and English. The evaluation of adverse events in anaesthesiology in Europe has been dealt with by Dutch and English studies. The Czech Republic was one of the 33 European countries in which the observational multi-centric study APRICOT was carried out.

\section{Table 2. Reported adverse events and practical recommendations}

Author, The authors' evaluation, research results.

publishing year, The most frequent adverse events and the systems they country have an impact on

de Santana Respiratory problems in $57.1 \%$ of cases, mostly aspiration

Lemos and de

Brito Poveda,

2019, Brazil

(50\%). Medical mistakes in $52.3 \%$, mostly incorrect medication (81.8\%). Cardiologic incidents in $52.3 \%$, included

bleeding (45.4\%) and arrhythmia (45.4\%). Neurological incidents in $47.6 \%$

Habre et The incidence of serious/critical events was $5.2 \%$

al., 2017,

Switzerland Respiratory 3.1\%

Cardiovascular instability $1.9 \%$, Cardiac arrest $0.03 \%$

Medical errors $0.2 \%$

Main serious event risk factors:

age $(p<0.0001)$,

anamnesis and physical condition $(p<0.0001)$

Williams et al., 2017, USA

The number of serious adverse events (at 10,000 anaesthesias):

Respiratory tract injuries 10, Airway patency problems 60 Consciousness under total anaesthesia 1, Cardiac arrest

74, Cardiovascular instability 111, Dermatological, musculoskeletal and burns 5, Problems with equipment 15 , Eye injury or the loss of sight 0 , Malignant hyperthermy 1 , Medical errors or reactions to treatment 34, Nervous system injuries 17, Other injuries 22, Perioperative death 12

Dias et al., 2016, Respiratory 55.5\%, Cardiovascular 11.1\%, Clinical assessment India $3.7 \%$, Documentation 1.8\%, Equipment 2.7\%, Medication $3.8 \%$, Regional anaesthesia 4.6\%, Organization and communication $0.9 \%$, Other $15.7 \%$

\section{Practical conclusions}

Care planning, effective communication and teamwork are crucial for the prevention of adverse events in anaesthesia care.

Large differences in the practice of paediatric anaesthesia in Europe were documented.

It is necessary to create standards and instructions for correct clinical practice in paediatric anaesthesia and implement strategies for quality improvement at the regional and national levels. These programmes and the implementation of incident reporting systems at the regional and national levels can contribute to the improvement of paediatric anaesthesia care in Europe.

Obligatory data input, interventions that affect the motivation and removal of obstacles when reporting an incident can increase perioperative incident reports and potentially increase patient safety.

Critical incident reporting can increase perioperative child safety Anaesthesiologists should be motivated to complete routine critical incident reporting.

Hospitals and anaesthesiology societies should implement hospital and national monitoring adverse event reporting systems. 
Table 2. (continued)

\begin{tabular}{|c|c|c|}
\hline $\begin{array}{l}\text { Author, } \\
\text { publishing year, } \\
\text { country }\end{array}$ & $\begin{array}{l}\text { The authors' evaluation, research results. } \\
\text { The most frequent adverse events and the systems they } \\
\text { have an impact on }\end{array}$ & Practical conclusions \\
\hline $\begin{array}{l}\text { Bellolio et al., } \\
\text { 2016a, USA }\end{array}$ & $\begin{array}{l}\text { The most frequent adverse events (incidence at } 1,000 \\
\text { sedations): } \\
\text { Hypoxia } 40.2 \text {, Vomiting } 16,4 \text {, Hypotension } 15.2 \\
\text { Serious adverse events that required urgent medical } \\
\text { intervention were rare: } \\
1 \text { aspiration in } 2,370 \text { sedations ( } 1.2 \text { to } 1,000), 1 \text { laryngospasm } \\
\text { in } 883 \text { sedations }(4.2 \text { to } 1,000), 2 \text { intubation in } 3,636 \\
\text { sedations ( } 1.6 \text { to } 1,000)\end{array}$ & $\begin{array}{l}\text { The data in this review provide quantitative risk estimates for } \\
\text { sedation procedures at emergency department. This will facili } \\
\text { decision-making, communication regarding risks and providi } \\
\text { consents for doctors and patients. }\end{array}$ \\
\hline $\begin{array}{l}\text { Bellolio et al., } \\
\text { 2016b, USA }\end{array}$ & $\begin{array}{l}\text { The most frequent adverse events (incidence at } 1,000 \\
\text { sedations): Vomiting } 55.5 \text {, Agitation } 17.9 \text {, Hypoxia } 14.8 \text {, } \\
\text { Apnoea } 7.1 \text {, Artificial ventilation } 5.0 \text { Incidence of serious } \\
\text { respiratory incidents: laryngospasm ( } 2.9 \text { to } 1,000 \text { sedations), } \\
4 \text { intubations in } 9,136 \text { sedations and } 0 \text { aspirations in } 3,326 \\
\text { sedations }\end{array}$ & $\begin{array}{l}\text { Study results provide quantitative risk estimates in sedated } \\
\text { children at emergency department. It is necessary to define a } \\
\text { standardize adverse effect reports during procedural sedation } \\
\text { of paediatric patients so that it is possible to better determin } \\
\text { optimal anaesthetics and procedures for specific clinical } \\
\text { indications. }\end{array}$ \\
\hline $\begin{array}{l}\text { Munting et } \\
\text { al., 2015, } \\
\text { Netherlands }\end{array}$ & $\begin{array}{l}\text { The most frequent documented AE: } \\
\text { Respiratory 5.8\%, Cardiovascular } 8.5 \% \text {, Laboratory } \\
\text { results } 36.4 \% \text {, Central nervous system 9.8\%, Equipment/ } \\
\text { organization 9.1\%, Patient injury } 4.3 \% \text {, Medical errors 5.6\%, }\end{array}$ & $\begin{array}{l}\text { Review of critical incidents that are related to anaesthesia } \\
\text { can guide the new reporting system and implementation of } \\
\text { preventative strategies to decrease the } \mathrm{AE} \text { in the future. }\end{array}$ \\
\hline
\end{tabular}
Other $15.0 \%$

Technical problems with regional anaesthesia (40 to 10,000 anaesthesias); hypotension (39 to 10,000 anaesthesias) and unexpected difficult intubation (20 to 10,000 anaesthesias)

\begin{tabular}{ll}
\hline de Graaff et & The most frequent AE: Breathing $46.5 \%$, Cardiovascular \\
al., 2015, & 131\%, Laboratory results $0.8 \%$, Central nervous system $1.1 \%$, \\
Netherlands & Equipment $2.8 \%$, Problems with locoregional anaesthesia \\
& $\begin{array}{l}\text { 6.2\%, Injuries } 13.1 \% \text {, Medical errors } 7.6 \% \text {, Organization and } \\
\text { communication } 3.4 \% \text {, Other } 5.5 \%\end{array}$ \\
& $\begin{array}{l}\text { Nurslings up to } 1 \text { year, children with ASA III and IV and acute } \\
\text { performances had a higher AE incidence. }\end{array}$
\end{tabular}

Mir Ghassemi et The most frequent serious $\mathrm{AE}$ in paediatric anaesthesia are al., 2015 Canada, related to the respiratory system, followed by cardiovascular UK problems. There were large differences in the reports. These were especially caused by the incorrect definition of the diagnostic criteria for individual complications. The most frequent complications in 100 anaesthesias: Difficult mask ventilation 6.6, Airway obstruction 2.2, Laryngospasm 0.9, Desaturation 2.4, Bradycardia 0.5

D'Angelo et al., Maternal death 30, Cardiac arrest 43, Heart attack 2 2014, USA Epidural abscess/meningitis 4, Epidural haematoma 1, Serious neurological damage 27, Aspiration 0, Intubation failure 10, High neuraxial block 58, Anaphylaxis 5, Respiratory arrest 25, Unrecognized spinal catheter 14

Serious complications related to anaesthesia were reported in 1 out of 3,000 patients. The most frequent serious complications were high neuraxial blocks, respiratory arrests during deliveries and unrecognized spinal anaesthetics application

Kurth et al., $\quad$ Respiratory incidents 22.6\%, Cardiac arrest 22\%,

2014, USA Cardiovascular incidents 13\%, Death 7\%, Tissue injuries 5.5\%, Airway injuries $4.9 \%$, Nervous system damage $3.4 \%$. Forced care escalation $20 \%$, which included: medical errors $65 \%$, equipment dysfunction $24 \%$, blood reactions $9 \%$, malignant hyperthermy $1 \%$, fire in the operating theatre $1 \%$

Wan et al., 2013, Respiratory system $69.8 \%$, Cardiovascular system $9.5 \%$, Singapore Pharmacology $4 \%$, Equipment $7.3 \%$, Iatrogenic $3.4 \%$, Metabolic 0.6\%, CNS 0.4\%, Procedural 3.1\%, Death $0.4 \%$, Other $1.5 \%$

The most frequent respiratory incident was laryngospasm, which occurred in $50.2 \%$ of all respiratory AEs. The most frequent cardiovascular $\mathrm{AE}$ was hypotension (40.3\%). There were 11 reported cases of cardiac arrest.
In this study, the level of $\mathrm{AE}$ in paediatric anaesthesia (3.4\%) is comparable with the incidence in adults (3.5\%), which were evaluated using the same system (previous studies reported a higher number of incidents in children than adults). This $\mathrm{AE}$ list can be used for the new $\mathrm{AE}$ reporting system in paediatric anaesthesia.

The data on acute serious $\mathrm{AE}$ in paediatric anaesthesia are incorrectly defined; there is a large variability in the reports. Future studies should be based on a standardized reporting system (with a hierarchic coding system).

The quantification of acute serious complications in paediatric anaesthesia is necessary for the creation of clinical instructions and educational basics.

Serious complications related to obstetric anaesthesia are rare. For this reason, it was impossible to identify the risk factors related to every one of them. Since most of these complications can lead to catastrophic consequences, it is important that perioperative teams be careful and prepared for quick diagnosis and treatment of any complication.

The results register co-operates with the Anesthesia Quality Institute to create complication registers regarding obstetric anaesthesia (as part of the incident reporting system regarding anaesthesia).

Education and QI (Quality Improvement) and SA (Safety Analytics) application in anaesthesia care workplaces are crucial strategies for the improvement of perioperative safety using WUS (Wake Up Safe).

$\mathrm{AE}$ reports are valuable because they provide a view of the healthcare system and help to identify active system errors. They will enable the formulation of effective preventative strategies. All clinical doctors should perceive $\mathrm{AE}$ analyses as an important instrument that could help patient safety to be improved. 
Table 2. (continued)

\begin{tabular}{|c|c|c|}
\hline $\begin{array}{l}\text { Author, } \\
\text { publishing year, } \\
\text { country }\end{array}$ & $\begin{array}{l}\text { The authors' evaluation, research results. } \\
\text { The most frequent adverse events and the systems they } \\
\text { have an impact on }\end{array}$ & Practical conclusions \\
\hline $\begin{array}{l}\text { Narasethkamol } \\
\text { et al., 2011, } \\
\text { Thailand }\end{array}$ & $\begin{array}{l}\text { Oxygen desaturation (23\%), Treatment requiring arrhythmia } \\
\text { (14\%), Equipment failure (13\%), Medical errors (9\%), Difficult } \\
\text { intubation (6\%), Esophageal intubation (5\%), Cardiac } \\
\text { arrest (5\%), Necessity of reintubation (4\%), Endobronchial } \\
\text { intubation (4\%). } \\
\text { Factors related to the incident: inexperience, insufficient } \\
\text { alertness, hurrying, incorrect decision, non-compliance of } \\
\text { instructions, and insufficient equipment maintenance. }\end{array}$ & $\begin{array}{l}\text { Suggested remedial strategies: quality improvement, trainings, } \\
\text { instructions for clinical practice, sufficient equipment } \\
\text { maintenance and the improvement of supervisions in clinical } \\
\text { practice. }\end{array}$ \\
\hline $\begin{array}{l}\text { MacLennan and } \\
\text { Smith, 2010, } \\
\text { England and } \\
\text { Wales }\end{array}$ & $\begin{array}{l}\text { Airways and breathing } 18.8 \% \text {, Cardiovascular } 5.9 \% \text {, } \\
\text { Medication } 35.6 \% \text {, Regional anaesthesia } 1.2 \% \text {, Equipment } \\
15.7 \% \text {, Communication } 8.6 \% \text {, Miscellaneous } 14.2 \% \text {, Death } 6 \\
\text { A wide database focus revealed a broad spectrum of clinical } \\
\text { and organizational incidents regarding paediatric anaesthesia. } \\
\text { Many reports lacked sufficient detail. }\end{array}$ & $\begin{array}{l}\text { Anaesthetists should be motivated to provide quality and full } \\
\text { descriptions of critical incidents to the national adverse events } \\
\text { reporting system. } \\
\text { This analysis of all-state reported incidents regarding } \\
\text { paediatric anaesthesia revealed several areas that are fit for } \\
\text { the improvement of clinical safety. Many reported incidents } \\
\text { could be prevented by the correct exercise of valid methods and } \\
\text { recommendations. }\end{array}$ \\
\hline $\begin{array}{l}\text { Gupta et al., } \\
\text { 2009, India }\end{array}$ & $\begin{array}{l}\text { Respiratory system } 39 \% \text {, Cardiovascular system } 32 \% \text {, } \\
\text { Respiratory + cardiovascular } 9.8 \% \text {, CNS 0.9\%, Cardiovacular + } \\
\text { CNS } 3.57 \% \text {, Respiratory + cardiovascular + CNS } 3.6 \% \text {, Other } \\
8.01 \% \\
\text { In this audit, the main cause of critical incidents regarding } \\
\text { anaesthesia was human error. }\end{array}$ & $\begin{array}{l}\text { Internal audits based on the recording of } \mathrm{AE} \text { in institutions are } \\
\text { necessary for anaesthesiology. The following analysis, sharing } \\
\text { experience and debating about } \mathrm{AE} \text { will enable the development of } \\
\text { new methods to prevent them from repeating. }\end{array}$ \\
\hline
\end{tabular}

An integrative review (de Santana Lemos and de Brito Poveda, 2019) analyzed 21 studies between 2009 and 2019 that were focused on adverse events regarding anaesthesia. The highest number of adverse events was related to respiratory and cardiovascular systems, medication and neurological problems. Adverse events in anaesthesia care and patient harm were related to errors that included active failures of medical workers in planning or performing procedures (failures caused by a human factor), as well as latent failures in organizational structure (system failure). The authors consider the reporting of near errors and adverse events occurrence in healthcare important, because they enable the identification of potential risks, the evaluation of structural imperfections, and equipment functioning. The lessons from these events contribute to trainings and the education of medical workers, and to the improvement of safety norms in healthcare. The authors of this review study state that the factors that contribute to the occurrence of adverse events include insufficient patient monitoring, non-compliance to the standards and care protocols, professional communication failures in exchanging information about patients, insufficient supervision over provided care, and insufficient teamwork in critical situations. They recommend maintaining care standards and protocols in practice, which could minimize the risks of medical worker failures and decrease deviations from recommended care. The use of control lists before every anaesthesia could effectively improve communication among doctors, nurses and other team members. It could also prevent critical scenarios and make team co-operation more effective. Expert societies and governments must support the development of healthcare systems and develop adverse event reporting systems. It is important to strengthen safety culture and motivate medical workers to report adverse events in order to share the experience on the national and international levels (de Santana Lemos and de Brito Poveda, 2019).

Between 2014 and 2015, the APRICOT study (Habre et al., 2017) was carried out in 33 European countries. The goal of this European, international, prospective and multi-centric study was to find the occurrence, nature, and consequences of serious adverse events in children undergoing anaesthesia, and to identify the related potential risk factors. They revealed a high level of serious critical incidents with a large variable occurrence in Europe (the incidence of serious perioperative critical incidents was $5.2 \%$ : respiratory $3.1 \%$, cardiovascular instability $1.9 \%$, cardiac arrest $0.03 \%$, medical errors $0.2 \%$ ). As risk factors of serious critical events, they identified age, co-morbidity, a child's physical condition and an inexperienced anaesthesiology team. In order to decrease adverse event risks, perioperative care of children under 3 years should be more specialized. These findings require the attention of national, regional and specialized scientific societies because they identify areas for further education, clinical research and the management of the increase of the quality of care. A certain centralization of care of the youngest and most ill children is necessary - because the care of more experienced teams contributes to a decrease in the incidence of adverse events.

The APRICOT study enabled us to see practical paediatric anaesthesia in 33 European countries and establish the incidence, nature, and results of critical events in healthcare centres. Since large differences in paediatric anaesthesia in European countries were documented, the necessity of implementing individual standards of correct clinical practice in paediatric anaesthesia in Europe was emphasized. Also emphasized was the necessity of creating a European register for monitoring perianaesthetic morbidity and mortality in children.

The goal of the American study of Williams et al. (2017) was to increase the level of adverse event reporting and describe the co-operation of anaesthesiologists regarding this activity. The University Children's Hospital in California (where the research was carried out) is a member of WUS (Wake Up Safe). They identified and classified incidents that fulfilled the criteria of WUS for serious AE, and evaluated the effects of 6 interventions that were focused on the increase of the number of reports. The most frequent adverse events were respiratory and cardiovascular problems and medical errors. Obstacles in reporting included: fear of repressive consequences, feeling 
of incompetence, insufficient knowledge about what an adverse event was, insufficient feedback from the hospital management, and the opinion of medical workers that reporting adverse events did not lead to system changes. These obstacles can be removed by educating employees and cultivating safety culture, where the hospital management supports adverse event reporting and provides feedback. This enables the strengthening of the role of anaesthesiologists regarding patient safety - because perioperative incident reports can increase patient safety.

The one-year prospective observational study (Dias et al., 2016) in an Indian faculty hospital aimed to evaluate the incidence of adverse events, classify them by degree of harm and analyze their relationship to a child's age. The incidence of adverse events reached almost $10 \%$. The most frequent were respiratory (55.5\%) and cardiovascular problems (11.1\%). The study results led to changes in the processes of anaesthesia care. Adverse event reporting systems provide the opportunity to increase perioperative child safety, and anaesthesiologists should be motivated to report adverse events. Hospitals and anaesthesiology societies should create hospital and national adverse event monitoring systems.

The goal of the American systematic meta-analysis of Bellolio et al. (2016a) was to evaluate the incidence of adverse events in adults undergoing sedation at emergency department. The meta-analysis included 55 studies (almost 10,000 sedations). The three most frequent adverse events included: hypoxia $4.02 \%$, vomiting $1.64 \%$ and hypotension $1.52 \%$. Critical incidents that required urgent intervention were rare: aspiration $0.12 \%$, laryngospasm $0.42 \%$ and necessary intubation $0.16 \%$. It was proven that sedation was safe if provided by trained personnel and when necessary equipment was available. It is necessary to consider the fact that patients undergoing sedation upon emergency department are exposed to higher complication risks that arise from their current health condition.

Bellolio et al. (2016b) carried out the meta-analysis of 41 studies whose goal was to evaluate the incidence of negative effects of sedation in children over the last 10 years. They wanted to record contemporary medical trends and monitoring procedures. Critical incidents, such as necessary intubation and aspiration, were very rare. Critical events included vomiting $5.55 \%$, agitation $1.79 \%$, hypoxia $1.48 \%$ and apnoea $0.71 \%$. Despite the progress in monitoring and medicine selection, there is no "safe" or "no-risk" medicine for paediatric sedation. A child's age and behaviour require a specific approach because dosages of medicine (similar medicines are often used in adults as well) in children are higher in comparison to physical weight - and children often need higher sedation. An important factor for safe sedation is consistent patient monitoring that is carried out by medical workers who are capable of solving complications. It is necessary to define and implement adverse event reporting standards during procedural sedation in paediatric patients to better determine optimal medicine and procedures for specific clinical indications.

The Dutch cohort study that was carried out between 2005 and 2011 by Munting et al., (2015) aimed to identify and analyze adverse events regarding anaesthesia in adults. Anaesthesiologists reported these events voluntarily and non-anonymously using AIMS (Anesthesia Information Management System) in a hospital that provided tertiary care. 110,310 operations were performed and 3,904 adverse events in 3.5\% anaesthetic procedures were reported. The most frequently reported incidents were cardiovascular complications (31\%) and technical problems with regional anaesthesia (10\%). The out- line of the incidence of critical incidents related to anaesthesia can help in the development of new adverse event reporting systems, as well as during the implementation of preventative strategies for the decrease of adverse events in anaesthesia care.

The goal of another Dutch cohort study that was carried out between 2007 and 2013 (de Graaff et al., 2015) was to identify and analyze critical incidents related to paediatric anaesthesia, identify the areas that needed the improvement of contemporary clinical practice, and design a specialized register of adverse events in paediatric anaesthesia. There were 35,190 anaesthesias in children up to 18 years and 1,214 reported adverse events. Although previous studies showed that there were more critical incidents in children (4.6\%) compared to adults $(1.2 \%)$, the level of critical incidents in children in this study (3.4\%) was comparable to adults (3.5\%) who were evaluated using the same system. Depending on age, critical incidents varied in type. Most cases in children were related to the respiratory system (46.5\%), and in adults most cases were related to the cardiovascular system (29.8\%). Critical incident reporting proved to be an effective system for the improvement of patient safety. The results can be used to create a new adverse event reporting system in paediatric anaesthesia.

The review study by Mir Ghassemi et al. (2015) that was carried out between 1984 and 2013 aimed to identify anaesthesia complications regarding their frequency and consequences. The study found that the most frequent acute critical incidents in paediatric anaesthesia are related to the management of airways, followed by cardiovascular problems. The reason for the problematic incident assessment was the large variability in reporting methods and form - especially insufficient definition of diagnostic criteria for complications. The authors suggest that future studies in this area should be based on the standardized diagnostic reporting system (possibly with a hierarchic coding system) - with the corresponding description of the circumstances of adverse events. Such studies can provide the basic diagnosis system that could be used for adverse event reporting, education, and creating clinical instructions and protocols.

The issue of adverse events in obstetric anaesthesia was dealt with by the project of D'Angelo et al. (2014). The goal of this 5-year project of data collection regarding obstetric complications (Serious Complication Repository, SCORE), created by the Society for Obstetric Anaesthesia and Perinatology (SOAP), was to find out the incidence of serious complications related to obstetric anaesthesia and to identify the risk factors associated with every complication. Serious complications were reported in 85 patients. The most frequent included high neuraxial blocks, respiratory arrests during labour, and unrecognized implemented spinal epidural catheters. Serious complications related to obstetric anaesthesia are rare but can lead to fatal consequences. The database adverse event reporting system, which captures information about clinical events and consequences that are related to every serious complication, can improve patient safety. So far, the SCORE project is the most complete database that evaluates complications regarding obstetric anaesthesia. In 2009, the American Society of Anesthesiologists founded the Anesthesia Quality Institute, which initiated its database of the National Anesthesia Clinical Outcomes Registry in 2010. Today, the SOAP co-operates with the Anesthesia Quality Institute in creating the complication registry for obstetric anaesthesia under the Anesthesia Quality Institute Anesthesia Incident Reporting System.

The study of Kurth et al. (2014) focused on the development and description of the multinational programme of 
Wake-Up Safe (WUS), which is focused on establishing the level of serious adverse events (Serious Adverse Events, SAE) in paediatric anaesthesia. WUS documented the incidence and types of SAE on the national level in paediatric anaesthesiology. They analyzed 734 serious adverse events in 736,365 cases of anaesthesia. The most frequent problems included respiratory problems, cardiac arrests, medical errors, equipment failure and cardiovascular problems.

Education and the implementation of QI (Quality Improvement) and safety studies at perioperative workplaces are the crucial strategies for the improvement of perioperative safety using WUS. Many anaesthesia organizations have founded subsidiaries to improve clinical care safety.

Wan et al. (2013) used retrospective analysis (10 years) to analyze critical incidents in paediatric anaesthesia and their related factors. In 75,331 anaesthesias carried out in a children's faculty hospital during the period of this study, 2,519 incidents (including 9 deaths) were recorded. Most reported events were related to the respiratory tract (69.8\%) and cardiovascular problems (9.5\%). Risk factors included age below one year and prematurely born children. Critical incident reporting is positive because it provides information about the care process and helps to identify active and system errors, which enables the formulation of effective preventative strategies. Due to the creation and maintenance of an organizational culture that supports the willingness of medical workers to report errors, there was a high and consistent level of adverse event reporting. In critical event analysis, all clinical workers should consider education as an important instrument for better patient safety.

The Thai prospective multi-centric study of Narasethkamol et al. (2011) established the frequency, clinical progress, factors that contribute and minimize adverse events in anaesthesia (using incident reports), and studied suitable remedial strategies in a Bangkok faculty hospital. There were 191 reported incidents in patients of different ages. The most frequent adverse events during anaesthesia included oxygen desaturation (23\%), arrhythmia requiring treatment (14\%), equipment failure $(13 \%)$ and medical errors (9\%). Common factors in the providers of perioperative care that were related to incidents included inexperience, insufficient attention, rushing, wrong decisions, not following instructions, and insufficient equipment maintenance. The suggested remedial strategies included activities that support quality improvement, further personnel training, instructions for clinical practice, equipment maintenance, and the improvement of clinical practice supervision.

MacLennan and Smith (2011) identified and analyzed critical incidents regarding paediatric anaesthesia from the National Reporting and Learning System (NRLS) in England and Wales. They analyzed 606 adverse events in children under 15 years and revealed a wide spectre of clinical and organizational incidents regarding paediatric anaesthesia. The most frequent incidents included medical errors (35\%), respiratory problems (19\%), and problems related to equipment (16\%). Many reported adverse events were not described in sufficient detail. Clinical incident reporting plays a crucial role in learning from problems - and this improves patient safety. This analysis of all-state reported incidents in paediatric anaesthesia revealed several areas for the improvement of clinical safety. Following implemented procedures and recommendations could prevent many incidents in clinical practice.

The Indian observational study of Gupta et al. (2009) focused on studying potential risk factors and analyzing events that lead to perioperative critical incidents. Their goal was to develop a critical incident reporting system. They carried out a one-year prospective analysis of 112 voluntarily reported perioperative critical incidents in patients of different ages. The most frequent critical incidents (48 out of 112) included respiratory (39\%) and cardiovascular (32\%). The causes included human error (85\%), pharmacological factors $(10.41 \%)$ and problems with equipment $(4.17 \%)$. Critical incident reporting systems can be beneficial for ensuring the quality of care, and establishing principles can prevent repeating errors and strengthen patient safety.

The most frequently reported/described adverse events/ incidents include respiratory problems, cardiovascular problems, medical errors and technical problems regarding regional anaesthesia. According to the authors, the factors that contribute to the incidence of adverse events include age, comorbidity and the physical condition of anaesthetized people (Bellolio et al., 2016a, b; de Santana Lemos and de Brito Poveda, 2019; Munting et al., 2015), as well as the inexperience of teams, not following standards and care protocols, errors in anaesthesia procedures, insufficient communication and team co-operation, or technical problems with the equipment (Gupta et al., 2009; de Santana Lemos and de Brito Poveda, 2019; Narasethkamol et al., 2011). The recommended effective methods for improving clinical practice include creating and following standards and clinical care protocols (Dias et al., 2016; Habre et al., 2017; de Santana Lemos and de Brito Poveda, 2019; MacLennan and Smith, 2010; Narasethkamol et al., 2011; Wan et al., 2013), using control lists before anaesthesia (de Santana Lemos and de Brito Poveda, 2019), sufficient expert preparation and corresponding equipment for anaesthesia care (Bellolio et al., 2016a, b; Narasethkamol et al., 2011).

The results of the mentioned studies show that the risks in anaesthesia care present a serious problem in public health. However, these risks are predictable and preventable. A significant part is related to human errors, whichare based on management errors or deviations from implemented practice. If error frequency is to be decreased, it is necessary to understand the processes of anaesthesia care more clearly, and identify the real causes of errors (including side factors) which contribute to the probability of committed errors (Gupta et al., 2009; de Santana Lemos and de Brito Poveda, 2019).

The mentioned studies agree that adverse event/incident reporting is an instrument for the improvement of safety and quality in anaesthesia care. They support or require the development of adverse event reporting systems on a national or international level.

\section{Conclusions}

Anaesthesiology was the first medical field to deal with patient safety. This remains its priority - and monitoring and evaluating adverse events seems to be an effective instrument for the improvement of quality and safety in anaesthesia care. Considering the incompatibility of adverse event/incident reporting in various databases, it would be convenient and effective to implement a standardized reporting system - which would enable data analyses and comparison. Supporting safety culture and motivating experts to report adverse events/ incidents and include it in their daily clinical practice are very important.

\section{Conflict of interests}

The authors have no conflict of interests to declare. 


\section{Nežádoucí události v anesteziologické péči}

\section{Souhrn}

Cílem přehledové studie bylo shrnout závěry výzkumů o hlášených nežádoucích událostech v anesteziologické péči u dětských a dospělých pacientů za posledních 10 let.

Metodika: Relevantní zdroje byly vyhledány ve vědeckých databázích: EBSCO, PubMed, Science Direct, Wiley a Scopus. Vybrané studie byly vyhledány pomocí klíčových slov: adverse events/incident/malpractice, anestesia, report, dále dle dalších stanovených kritérií (plný text, anglický jazyk, období publikace výsledků výzkumu posledních deset let, tedy 2009-2019, lidský subjekt). Do konečného přehledu bylo zařazeno 15 studií.

Výsledky: Studie (analytické, prospektivní, retrospektivní, kohortové, observační, systematický přezkum a metaanalýza) většinou specifikují oblasti a frekvenci hlášených nežádoucích událostí a věnují se efektivitě postupu hlášení a jeho zavádění do klinické praxe. Jako nejčastější nežádoucí události, ke kterým došlo v průběhu anesteziologické péče, byly identifikovány problémy respiračního a kardiovaskulárního charakteru a medikační pochybení, míra jejich výskytu byla různá v závislosti na věku pacientů. Závěr: Sledování a hodnocení nežádoucích událostí se jeví jako efektivní nástroj pro zvyšování kvality a bezpečnosti péče v anesteziologické praxi. Problémem je neochota zdravotnických pracovníků se na hlášení nežádoucích událostí podílet a nekompatibilita databází shromažd'ujících hlášení o nežádoucích událostech v anesteziologické péči.

Klíčová slova: anestezie; bezpečnost pacienta; hlášení; nežádoucí událost; perioperační péče

\section{References}

1. Bellolio MF, Gilani WI, Barrionuevo P, Murad MH, Erwin PJ, Anderson JR, Miner JR, Hess EP (2016a). Incidence of adverse events in adults undergoing procedural sedation in the emergency department: a systematic review and meta-analysis. Acad Emerg Med 23(2): 119-134. DOI: 10.1111/acem.12875.

2. Bellolio MF, Puls HA, Anderson JL, Gilani WI, Murad MH, Barrionuevo P, et al. (2016b). Incidence of adverse events in paediatric procedural sedation in the emergency department: a systematic review and meta-analysis. BMJ Open 6(6): e011384. DOI: 10.1136/bmjopen-2016011384.

3. Choy CY (2008). Critical incident monitoring in anaesthesia. Curr Opin Anaesthesiol 21(2): 183-186. DOI: 10.1097/ ACO.0b013e3282f33592.

4. ČSARIM (2017). Zásady bezpečné anesteziologické péče. Doporučený postup. [online] [cit. 2019-06-15]. Available from: https://www.csarim.cz/content/uploads/2018/11/doporucenypostup-zasady-bezpecne-anesteziologicke-pece-2017.pdf

5. D’Angelo R, Smiley RM, Riley ET, Segal S (2014). Serious Complications Related to Obstetric AnesthesiaThe Serious Complication Repository Project of the Society for Obstetric Anesthesia and Perinatology. Anesthesiology 120(6): 1505-12. DOI: 10.1097/ALN.0000000000000253.

6. De Graaff JC, Sarfo MC, Van Wolfswinkel L, van der Werff DB, Schouten AN (2015). Anesthesia-related critical incidents in the perioperative period in children; a proposal for an anesthesiarelated reporting system for critical incidents in children. Paediatr Anaesth 25(6): 621-629. DOI:10.1111/pan.12623.

7. de Santana Lemos C, de Brito Poveda V (2019). Adverse Events in Anesthesia: An Integrative Review. J Perianesth Nurs 34(5): 978-981. DOI: 10.1016/j.jopan.2019.02.005.

8. Dias R, Dave N, Chiluveru S, Garasia M (2016). Critical incidents in paediatric anaesthesia: A prospective analysis over a 1 year period. Indian J Anaesth 60(11): 801. DOI: $10.4103 / 0019-5049.193658$.

9. Gaba D (2000). Anaesthesiology as a model for patient safety in health care. BMJ 320(7237): 785-788. DOI: 10.1136/ bmj.320.7237.785

10. Gupta S, Naithani U, Brajesh SK, Pathania VS, Gupta A (2009). Critical incident reporting in anaesthesia: a prospective internal audit. Indian J Anaesth 53(4): 425.

11. Habre W, Disma N, Virag K, Becke K, Hansen TG, Jöhr M, et al. (2017). Incidence of severe critical events in paediatric anaesthesia (APRICOT): a prospective multicentre observational study in 261 hospitals in Europe. Lancet Respir Med 5(5): 412-425. DOI: 10.1016/S2213-2600(17)30116-9.

12. Kurth CD, Tyler D, Heitmiller E, Tosone SR, Martin L, Deshpande JK (2014). National pediatric anesthesia safety quality improvement program in the United States. Anesth Analg 119(1): 112-121. DOI: 10.1213/ ANE.0000000000000040.

13. Levinson DR (2010). Adverse Events In Hospitals: National Incidence Among Medicare Beneficiaries. Office of Inspector General, U.S. Department of Health and Human Services. [online] [cit. 2019-05-13]. Available from: https://oig.hhs.gov/ oei/reports/oei-06-09-00090.pdf

14. MacLennan AI, Smith AF (2011). An analysis of critical incidents relevant to pediatric anesthesia reported to the UK National Reporting and Learning System, 2006-2008. Paediatr Anaesth 21(8): 841-847. DOI: 10.1111/j.14609592.2010.03421.x.

15. Mahajan RP (2010). Critical incident reporting and learning. Br J Anaesth 105(1): 69-75. DOI: 10.1093/bja/aeq133.

16. Mellin-Olsen J, Staender S, Whitaker DK, Smith AF (2010). Helsinki Declaration for Patient Safety in Anaesthesiology. Eur J Anaesthesiol 27(7): 592-597. DOI: 10.1097/ EJA.0b013e32833b1adf.

17. Mir Ghassemi A, Neira V, Ufholz LA, Barrowman N, Mulla J, Bradbury CL, Bould MD (2015). A systematic review and metaanalysis of acute severe complications of pediatric anesthesia. Paediatr Anaesth 25(11): 1093-1102. DOI: 10.1111/pan.12751.

18. Munting KE, van Zaane B, Schouten AN, van Wolfswinkel L, de Graaff JC (2015). Reporting critical incidents in a tertiary hospital: a historical cohort study of 110,310 procedures. Can J Anaesth 62(12): 1248-1258. DOI: 10.1007/s12630-0150492-y.

19. Narasethkamol A, Charuluxananan S, Kyokong O, Premsamran P, Kundej S (2011). Study of model of anesthesia related adverse event by incident report at King Chulalongkorn Memorial Hospital. J Med Assoc Thai 94(1): 78-88. PMID: 21425732.

20. Pokorná A, Mužík J, Štrombachová V (2018). Nežádoucí události při poskytování zdravotních služeb a jejich sledování na národní/centrální úrovni. Management rizik ve zdravotnictví 2(1): 16-21.

21. Smith AF, Mahajan RP (2009). National critical incident reporting: improving patient safety. Br J Anaesth 103(5): 623-625. DOI: 10.1093/bja/aep273.

22. Vlayen A, Verelst S, Bekkering GE, Schrooten W, Hellings J, Claes N (2012). Incidence and preventability of adverse events requiring intensive care admission: a systematic review. 
J Eval Clin Pract 18(2): 485-497. DOI: 10.1111/j.13652753.2010.01612.x.

23. Wan S, Siow YN, Lee SM, Ng A (2013). Audits and critical incident reporting in paediatric anaesthesia: lessons from 75,331 anaesthetics. Singapore Med J 54(2): 69-74. DOI: 10.11622/smedj.2013027.

24. Williams GD, Muffly MK, Mendoza JM, Wixson N, Leong K, Claure RE (2017). Reporting of perioperative adverse events by pediatric anesthesiologists at a tertiary children's hospital: targeted interventions to increase the rate of reporting. Anesth Analg 125(5): 1515-1523. DOI: 10.1111/j.13652753.2010.01612.x.

25. Woods DM, Johnson J, Holl JL, Mehra M, Thomas EJ, Ogata ES Lannon C (2005). Anatomy of a patient safety event: a pediatric patient safety taxonomy. Qual Saf Health Care 14(6): 422-427. DOI: 10.1136/qshc.2004.013573. 